\title{
Using Fine-Grained Sediment and Wave Attenuation as a New Measure for Evaluating the Efficacy of Offshore Breakwaters in Stabilizing an Eroded Muddy Coast: Insights from Ca Mau, the Mekong Delta of Vietnam
}

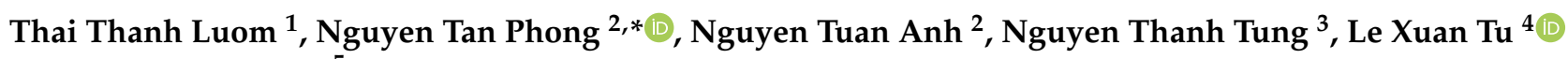 \\ and Tran Anh Duong 5 \\ 1 Institute of Science, Technology and Training, Kien Giang University, Rach Gia 91076, Vietnam; \\ thaithanhluom@vnkgu.edu.vn \\ 2 Faculty of Environment and Labour Safety, Ton Duc Thang University, Ho Chi Minh City 700000, Vietnam; \\ 186010005@student.tdtu.edu.vn \\ 3 Provincial Level Irrigation \& Water Drainage, Ca Mau 98110, Vietnam; nguyentungcctl@gmail.com \\ 4 Southern Institute of Water Resources Research, Ho Chi Minh City 72704, Vietnam; xuantut1@gmail.com \\ 5 Institute of Applied Science, Ho Chi Minh City University of Technology (HUTECH), \\ Ho Chi Minh City 700000, Vietnam; trananhduong1981@gmail.com \\ * Correspondence: nguyentanphong@tdtu.edu.vn
}

Citation: Luom, T.T.; Phong, N.T.; Anh, N.T.; Tung, N.T.; Tu, L.X.; Duong, T.A. Using Fine-Grained Sediment and Wave Attenuation as a New Measure for Evaluating the Efficacy of Offshore Breakwaters in Stabilizing an Eroded Muddy Coast: Insights from $\mathrm{Ca} \mathrm{Mau,} \mathrm{the} \mathrm{Mekong}$ Delta of Vietnam. Sustainability 2021, 13, 4798. https://doi.org/10.3390/ su13094798

Academic Editor: Tomonobu Senjyu

Received: 22 March 2021

Accepted: 19 April 2021

Published: 25 April 2021

Publisher's Note: MDPI stays neutral with regard to jurisdictional claims in published maps and institutional affiliations.

Copyright: (C) 2021 by the authors. Licensee MDPI, Basel, Switzerland. This article is an open access article distributed under the terms and conditions of the Creative Commons Attribution (CC BY) license (https:// creativecommons.org/licenses/by/ $4.0 /)$.

\begin{abstract}
Offshore breakwaters can be effective in reducing the energy of incident waves through dissipation, refraction or reflection. Breakwaters are increasingly constructed to stabilize eroded muddy coasts, particularly in developing countries. Accumulation of fine-grained sediment and wave attenuation are two attributes of a stable muddy coast. Effective interventions in stabilizing eroded muddy coasts include two important elements: accumulation of fine-grained sediment and wave reduction. The efficacy of offshore breakwaters in stabilizing eroded muddy coasts is, however, not yet adequately understood. A crucial question needing attention is whether accumulation of fine-grained sediment and wave attenuation should be used in evaluating the efficacy of these offshore breakwaters in stabilizing eroded muddy coasts. To address this issue, a pile-rock offshore breakwater in Huong Mai, Tieu Dua of Ca Mau, Vietnam was selected as an appropriate example in this regard. Accumulation of fine-grained sediment and wave attenuation were tested as means to investigate the efficacy of the Huong Mai structure in stabilizing the eroded muddy coast. The study was undertaken using field-based measurements and semi-structured interviews in three stages between October 2016 and December 2020. We found that this structure has had limited efficacy in stabilizing the eroded muddy coast. The structure was effective in dissipating the energy of incident waves, but we found no evidence of fine-grained sediment accumulation due to an inappropriate structural design. There was also no monitoring system in place, leading to difficulties in evaluating its efficacy in terms of wave attenuation and accumulation of fine-grained sediment. The gaps between the shoreline and the structure have not been adequately explained, resulting in substantial challenges in replicating the structure elsewhere. The Huong Mai structure should be strengthened using supplementary measures and granulometric tests in order to improve the efficacy in stabilizing eroded muddy coasts. The methods in this study provide new insights in this regard.
\end{abstract}

Keywords: fine-grained sediment; structural design; turbidity; transplantation; wave attenuation; natural regeneration

\section{Introduction}

Offshore breakwaters aim to manage shoreline change or eliminate erosion by reducing the energy of incident waves through dissipation, refraction and/or reflection [1]. These breakwaters are constructed parallel to the shore in more exposed settings or deeper water 
at a certain distance from the shoreline [1,2]. They include geo-tubes, tubular structures, reef balls (concrete artificial reef modules), stable underwater mud berms [3], emergent and low-crested structures and detached breakwaters [1]. To date, these offshore breakwaters are frequently evaluated on the basis of economic viability or the physical impacts caused by their construction. Evaluations may be undertaken using satellite image analysis in combination with ground truthing [4,5], algorithmic modeling with a cost analysis [6] or on cost analysis alone [7].

Offshore breakwaters have been recently constructed in combination with transplantation of mangrove seedlings to control eroded muddy coasts, particularly in developing countries such as Malaysia [8,9], Thailand [10] and Vietnam [11,12]. Theoretically, a muddy coast is predominantly influenced by a stabilization process where fine-grained sediment gradually accumulates through dissipation of the energy of incident waves, followed by natural mangrove regeneration $[13,14]$. In practice, effective intervention to stabilize eroded muddy coasts includes two important elements: accumulation of fine-grained sediment and wave attenuation [15].

Therefore, whether fine-grained sediment accumulation and wave reduction are feasible criteria for evaluating the efficacy of offshore breakwaters in stabilizing eroded muddy coasts remains a crucial question, especially in the context where offshore breakwaters are prioritized for controlling erosion, as is the case in the Vietnamese Mekong Delta among other regions.

\subsection{Coastal Erosion Control in the Mekong Delta of Vietnam}

By 2015, many coastal areas of the Mekong Delta of Vietnam had become severely eroded $[16,17]$ due to human activities and natural factors $[16,18]$. Since 2013, the Vietnamese Government has aimed to promote sustainable use of the Mekong coast in the context of increasing socioeconomic development, climate change and sea level rise. In order to achieve this, various programs were established in order to protect the Vietnamese and Mekong Delta coasts from the negative effects of climate change and sea level rise. The programs include the Program on Strengthening and Upgrading of the Sea Dyke Systems from Quang Ngai to Kien Giang provinces [19], the Strategy for Managing Integrated Coastal Zones of Vietnam [20], and The Regulations on Managing Protected Forests [21]. A total of approximately USD 200 million was invested to improve the management of mangrove forests and coastal protection in 2017 [22]. In many coastal provinces of the Vietnamese Mekong Delta, existing sea dykes were upgraded and new sea dykes constructed in combination with the transplantation of mangrove seedlings. However, the sea dykes did not function as expected [23]. By 2017, a total of $268 \mathrm{~km}$ of the coast (approximately $45 \%$ of the entire coast) had been eroded [22], with a maximum retreat rate of $45 \mathrm{~m}$ per year with 15,000 ha of coastal mangrove forests lost) [22].

\subsection{Ca Mau Case and Our Aims}

Ca Mau, located in the Mekong Delta of Vietnam, contains approximately $105 \mathrm{~km}$ of coastline. Half of the entire coastline of Ca Mau had become severely eroded with 8870 ha of mangrove forests lost [24]. Mangrove belts in many areas were more or less $200 \mathrm{~m}$ in width [24]. Ca Mau province had implemented the Vietnamese coastal protection programs. Shoreline structures and offshore breakwaters were constructed along the Ca Mau coast as measures for eliminating the erosion. By 2019, $28.5 \mathrm{~km}$ of these structures had been built from a capital investment of approximately USD 5 million [24]. An offshore breakwater constructed in Huong Mai in Tieu Dua (hereafter simply called HMS) was one of a few structures which were still operational on the western side of Ca Mau province in 2019 [24]. Other structures were too small in scale or newly established to demonstrate their efficacy towards protecting eroded coasts in Ca Mau. The HMS was a source of pride for the Vietnamese Government and Ca Mau PPC because of its longevity. However, its efficacy in stabilizing the muddy coast was not comprehensively evaluated, nor lessons learnt. Regardless, the HMS structural design was then replicated with structural adjustments (i.e., 
widening gaps and with or without transplantation of seedlings of mangrove species, or adjusting positions of the structures) in other districts of $\mathrm{Ca}$ Mau province such as Khanh Binh Tay and Tran Van Thoi [24].

In 2011, the Vietnamese Government, through the Ministry of Finance, entered into a loan agreement with the German Government to implement a proposed project 'Integrated Coastal Protection and Mangrove Belt Rehabilitation Project mangrove belt rehabilitation project in Ca Mau and Kien Giang Provinces'. This project, planned for implementation in 2022, primarily aims to construct coastal structures, both shoreline and offshore, to protect the shoreline and mangrove forests [25]. The HMS design was used as a technical reference in other areas in Ca Mau [26] and Kien Giang [27]. Other provinces of the Mekong Delta then became interested in replicating the HMS design as an effective erosion control in their regions. In 2019, Kien Giang replicated the HMS design in controlling erosion in two districts of Kien Giang province (Vam Ray of Hon Dat district and Xeo Nhau of the An Minh district). The Kien Giang replications were undertaken along with mangrove transplantation.

In 2017, the offshore breakwaters in Khanh Binh Tay and Tran Van Thoi, Ca Mau province were evaluated with respect to wave attenuation through the simulation of the technical structural designs of Khanh Binh Tay and Tran Van Thoi in combination with field-based measurements in Ca Mau [12]. However, the accumulation of fine-grained sediment was not measured. By 2019, however, these newer structures were shown to be inadequate for protecting shorelines under the influence of strong waves at high tides, and sea dykes located landwards behind these breakwaters were severely damaged [28].

Consequently, we selected the HMS as a case study to investigate the above issues. In this study, we aimed to investigate the mechanisms by which the HMS contributed toward coastal stabilization. The investigation was undertaken using two elements: accumulation of fine-grained sediment, and wave attenuation. We also aimed to identify successful strategies and interventions so that the HMS can be effectively replicated both in the Mekong Delta area and elsewhere in a wider region. In order to achieve this, satellite images were analyzed in order to understand the extent of the stabilization process to which the HMS contributed. Field visits were completed together with semi-structured interviews and we referred to the literature to gain an insight into how the HMS contributed to stabilization of the eroded muddy coast, and draw lessons in order to improve its efficacy in the future.

\section{Materials and Methods}

\subsection{Site Description}

Ca Mau is located in the southernmost part of the Vietnamese Mekong Delta, bordered by the East Sea in the East and the West Sea on the Thai Gulf (Figure 1).

Ca Mau, with a total shoreline of $254 \mathrm{~km}$, contains 18,180 ha of mangrove forests and intertidal mudflats [11]. Ca Mau has two relatively distinct monsoons. The southwest monsoon operates from May to October, with wind speeds from 1.6 to $2.0 \mathrm{~m} / \mathrm{s}$ (maximum of $4.5 \mathrm{~m} / \mathrm{s}$ ). The northeast monsoon operates from November to April, with an average wind speed of 1.4 to $3.0 \mathrm{~m} / \mathrm{s}$, with a maximum intensity from February to April.

$\mathrm{Ca}$ Mau is hydrologically influenced by the tidal regimes of the East Sea and West Sea, and rainfall [11]. Tides of the East Sea are semi-diurnal with diurnal inequality while the West Sea is characterized by diurnal tides with diurnal inequality. The tidal range of the East Sea is approximately between +1.8 and $+2.2 \mathrm{~m}$ while the West Sea has a maximum tidal range of $+1.0 \mathrm{~m}[11]$.

Huong Mai in Tieu Dua, located on the western side of Ca Mau (Figure 1), is influenced by the tidal range of The Gulf of Thailand, with diurnal tides with diurnal inequality [11]. The maximum tidal range is approximately $1.0 \mathrm{~m}$ high [11]. The area was severely eroded by 2010, with many Rhizophora trees uprooted [26]. 

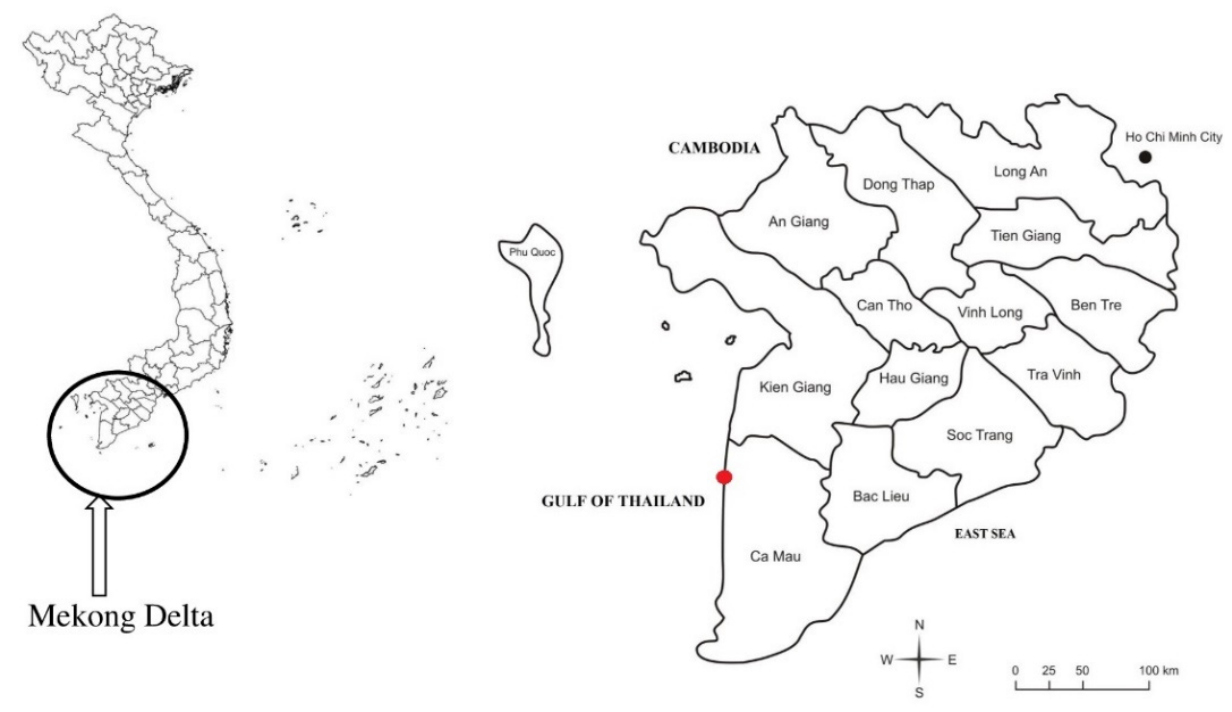

Figure 1. The location of the Mekong Delta of Vietnam (left) and Huong Mai, Tieu Dua (red dot) in Ca Mau province, the Mekong Delta (right). The maps are derived from Google.

Construction of the HMS commenced in late 2010, and was completed in 2013. With a total length of approximately $6318 \mathrm{~m}$, it cost approximately USD 1400 per meter. The HMS rises $+1.5 \mathrm{~m}$ above the mud surface, and is composed of two lines of concrete piles with $2.6 \mathrm{~m}$ spacing. Melaleuca poles were used as base support that prevents granite rock from sinking in the mud. Granite rocks were used for filling the gaps between the concrete piles [11]. The technical design and elements are provided in Figure 2.

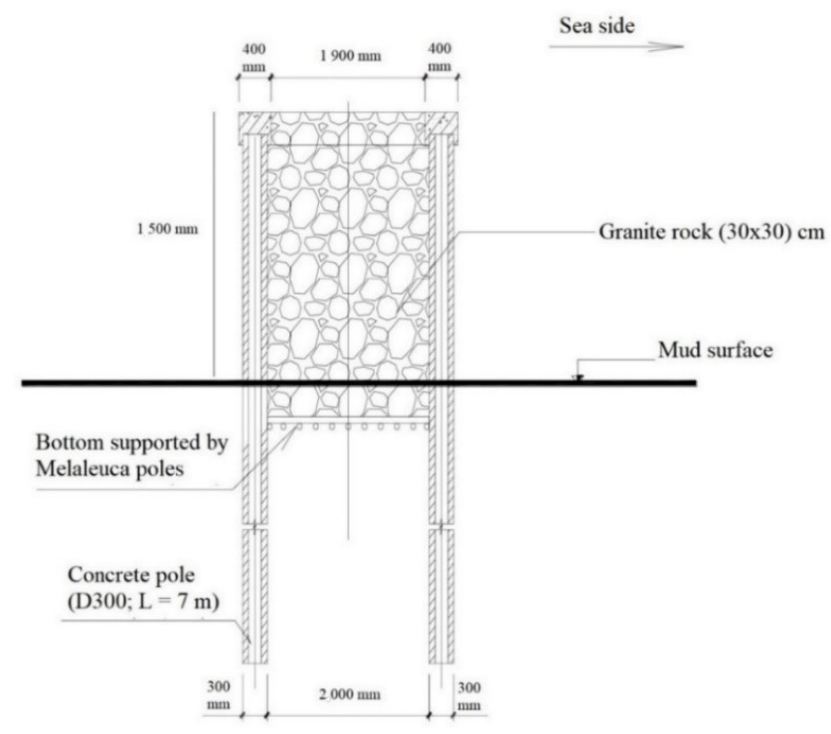

Figure 2. The HMS's structural design (adapted from [11]).

The HMS is in four sections, with three openings, created for local boating purposes. Gaps between the structure and the shoreline vary from section to section. Of the four sections, three (Sections A, B and C) incorporated landfill in order to elevate the soil surface, where seedlings were transplanted. Six-month-old seedlings of Avicennia marina were transplanted in straight lines at a density of 10,000 seedlings/ha in the gaps (Figures 3 and 4 and Table 1). 


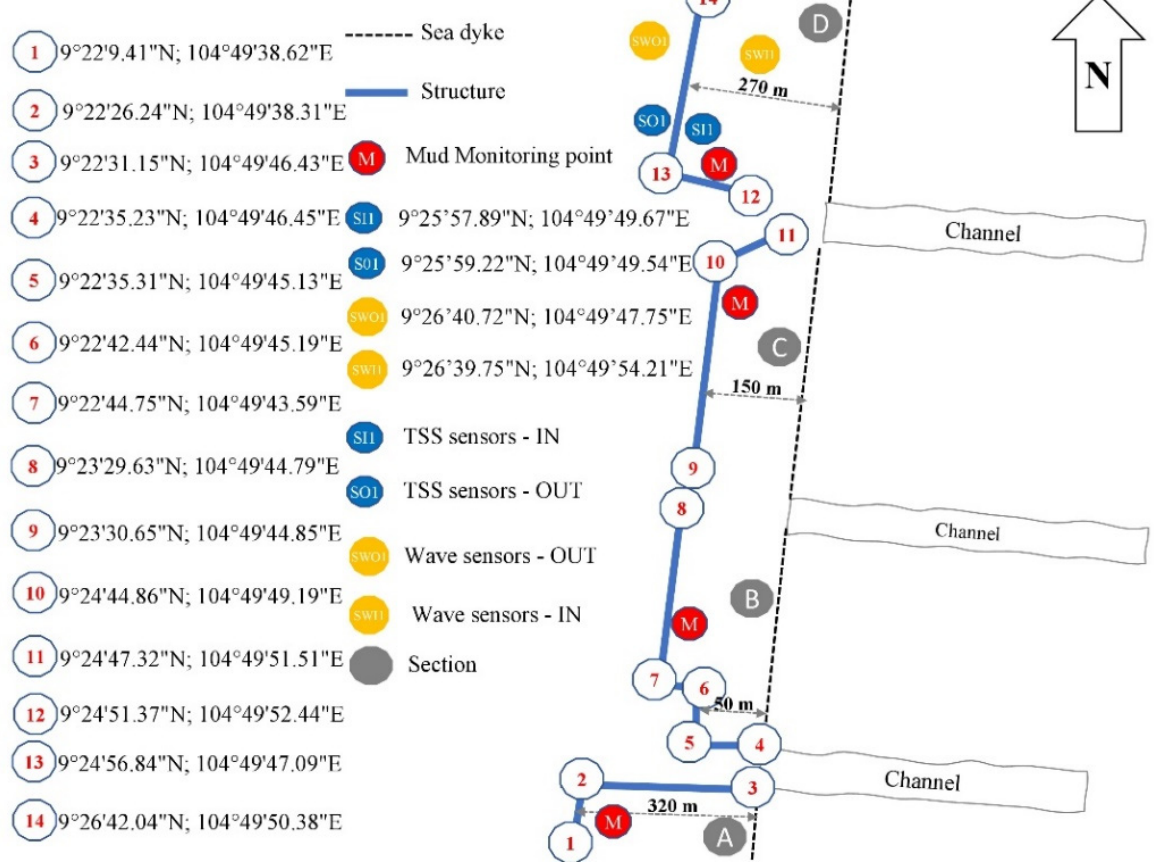

Figure 3. The HMS layout.

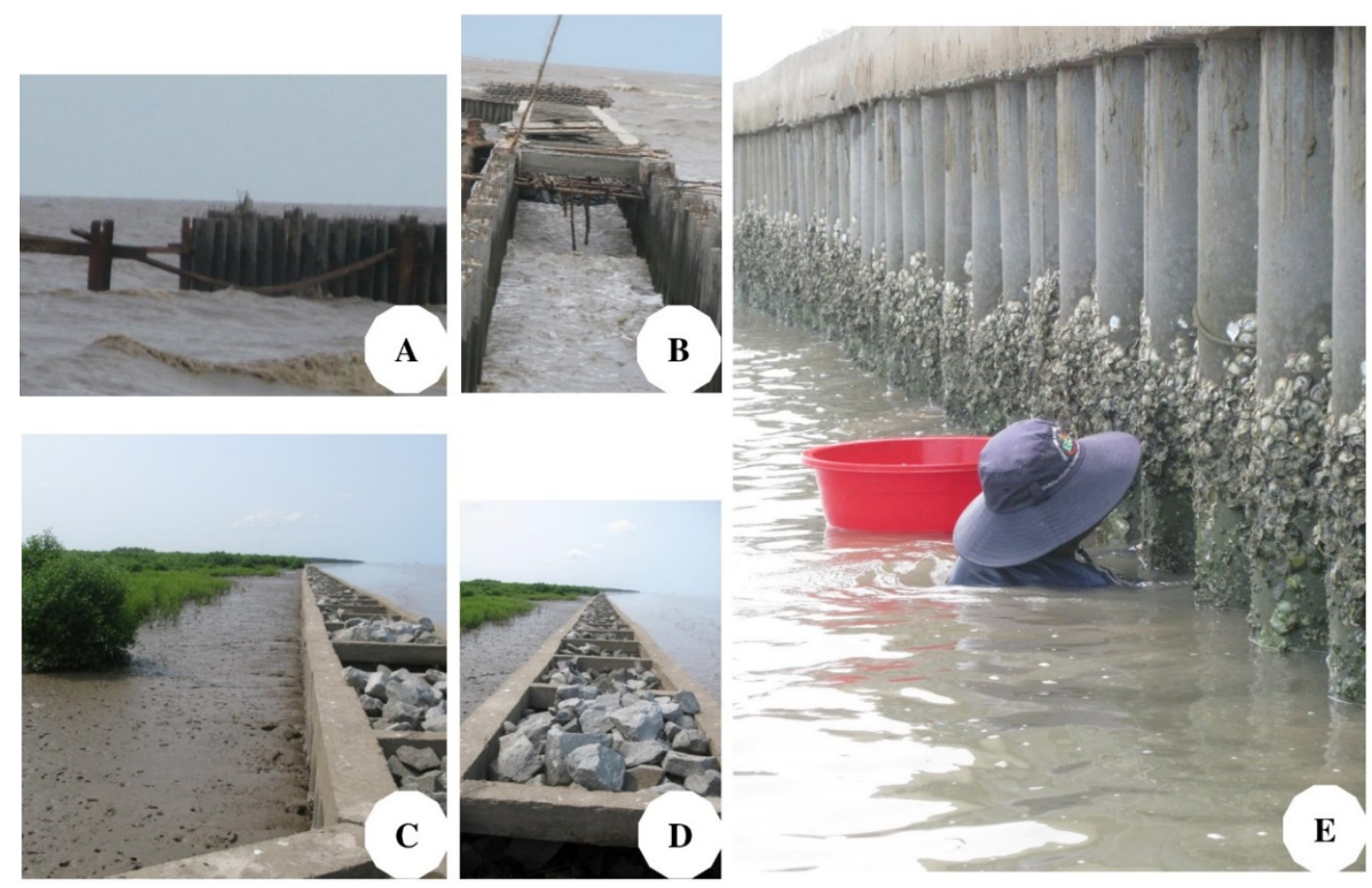

Figure 4. The HMS construction. (A,B) Two lines of concrete piles were first constructed. (C,D) Granite rocks filled the gaps between the two lines with 6-month-old seedlings of Avicennia marina transplanted in the gaps between the pile lines and the sea dyke. (E) Low tides against the height of the structure. 
Table 1. Locations, original status and interventions.

\begin{tabular}{|c|c|c|c|}
\hline Section & Location & Status in 2013 & Intervention \\
\hline A & $\begin{array}{l}\text { 1,2,3 (maximum } \\
\text { width-approximately } 320 \mathrm{~m} \\
\text { from the current sea dyke) }\end{array}$ & $\begin{array}{ll}\text { - } & \text { Entrance to channel } \\
\text { - } & \text { Fragmented mangrove } \\
\text { patches } \\
\text { - } & \text { Elevated soil surface/landfill }\end{array}$ & $\begin{array}{l}\text { - } \quad \text { Structure constructed with opening } \\
\text { 6-month-old seedlings of Avicennia } \\
\text { marina transplanted in straight lines } \\
(10,000 \text { seedlings } / \text { ha })\end{array}$ \\
\hline B & $\begin{array}{l}\text { 4,5,6,7,8 (minimum } \\
\text { width-approximately } 50 \mathrm{~m} \\
\text { from the current sea dyke }\end{array}$ & $\begin{array}{ll}\text { - } & \text { Entrance to channel } \\
\text { - } & \text { Fragmented mangrove } \\
\text { patches } \\
\text { - } & \text { Elevated soil surface/landfill }\end{array}$ & $\begin{array}{l}\text { - } \quad \text { Structure constructed with opening } \\
\text { 6-month-old seedlings of Avicennia } \\
\text { marina transplanted in straight lines } \\
(10,000 \text { seedlings } / \text { ha })\end{array}$ \\
\hline $\mathrm{C}$ & $\begin{array}{l}\text { 9,10,11 (maximum } \\
\text { width-approximately } 150 \mathrm{~m} \\
\text { from the current sea dyke) }\end{array}$ & $\begin{array}{ll}\text { - } & \text { Entrance to channel } \\
\text { - } & \text { Fragmented mangrove } \\
\text { patches } \\
\text { - } & \text { Elevated soil surface/landfill }\end{array}$ & $\begin{array}{l}\text { - } \quad \text { Structure constructed with opening } \\
\text { 6-month-old seedlings of Avicennia } \\
\text { marina transplanted (in straight linea } \\
\text { 10,000 seedlings/ha) }\end{array}$ \\
\hline $\mathrm{D}$ & $\begin{array}{l}12,13,14 \text { (maximum } \\
\text { width-approximately } 270 \mathrm{~m} \\
\text { from the current sea dyke) }\end{array}$ & $\begin{array}{l}\text { - Fragmented mangrove } \\
\text { patches } \\
\text { - } \quad \text { Deep liquid mud }\end{array}$ & $\begin{array}{l}\text { - } \quad \text { Structure constructed } \\
\text { 6-month-old seedlings of Avicennia } \\
\text { marina transplanted in straight lines } \\
(10,000 \text { seedlings } / \text { ha })\end{array}$ \\
\hline
\end{tabular}

A simulation had been undertaken in the site with respect to wave height, current speed and velocity before the HMS was completed. Waves were predicted at a maximum height of $0.25 \mathrm{~m}$ behind the HMS; current $0.18 \mathrm{~m} / \mathrm{s}$; and velocity $0.7 \mathrm{~m} / \mathrm{s}$ [29]. However, no ongoing monitoring system was put in place. Accumulations of fine-grained sediment were measured twice: February 2014 and November 2020, the time when this study was undertaken (Figure 3). Neither the survival of transplanted seedlings nor wave attenuation resulting from the HMS were measured.

\subsection{Methods}

The current data recorded in Ca Mau were not detailed enough to understand the efficacy of the HMS in stabilizing the eroded muddy coast. However, additional ad hoc monitoring and analysis were undertaken in three stages between October 2016 and December 2020 in order to achieve the objectives of the study. The first stage occurred between October 2016 and July 2017. This stage involved the collection of reports relevant to the HMS and measurement of total suspended sediment (TSS) at the site. The measurement was undertaken using four turbidity sensors (VisoTurb ${ }^{\circledR} 700$ IQ and ViSolid ${ }^{\circledR} 700$ IQ sensors, WTW MIQ-Xylem Analytics-UK) in Section D. The sensors were placed in two pairs on either side of the HMS with a $7.0 \mathrm{~m}$ spacing (Figure 3) over four hours. This stage provided knowledge of the extent of turbidity and levels of Total Suspended Sediment (TSS) to which the HMS contributed, and assisted in developing open-ended questions which were subsequently used for semi-structured interviews with staff working for the Ca Mau government agencies. Semi-structured questions focused on structural design, implementation process and monitoring and evaluation.

The second stage, in August 2020, aimed to measure wave spectrum, wave height and wave transmission coefficient $\left(K_{t}\right)$ using the methods recommended by Tu et al [12]. The measurement was undertaken over 2 days using sensors (Wave Gauge Blue, produced by Ocean Sensor Systems Inc., USA), which were installed at Section D (80 m in front of the structure and $120 \mathrm{~m}$ behind the structure). This stage provided knowledge of the wave spectrum and wave attenuation provided by the HMS. where

The wave transmission coefficient $K_{t}=\frac{H_{m 0, t}}{H_{m 0, i}}$

$H_{m 0 . t}$ is the height of transmitted waves. 
$H_{m 0 . i}$ is the height of incident waves.

The last stage of this study involved field visits to the site which were organized between June and December 2020. During the field trips, six boat visits were made to the HMS site at high and low tides in order to conduct field-based observations. Three semi-structured interviews were undertaken with four technical staff working for the $\mathrm{Ca}$ Mau government agencies, Section of Irrigation and Drainage of Ca Mau province (two staff), Sea Dyke and Sluice Gate Management Section (one), and the Forestry section of the Department of Agriculture and Rural Development of Ca Mau province (one). Each interview lasted one hour. Data in relation to mud accumulation inside the sections were obtained during these interviews. The accumulation of fine-grained sediment was calculated by comparing the two measurements undertaken in February 2014 and November 2020 , which was used as additional evidence of the stabilization process. Satellite images of the site between 2013 and 2020 were retrieved and analyzed to gain an insight into the extent of stabilization to which HMS had contributed instead. The year 2013 was selected for analysis because HMS was completed in 2013. This stage produced a deep insight into monitoring and evaluation, and a knowledge of how effectively the HMS worked towards stabilizing the eroded Huong Mai coast.

The study primarily focused on measuring the sediment accumulation and wave attenuation around the HMS, but without granulometric tests. Analysis of the efficacy of the HMS therefore necessitated further granulometric information, particularly regarding the conditions for mobilization of muddy sediments in the channel openings and the gaps. This information is necessary in order to understand how grain size influences sediment transport rates. Unfortunately, time constraints and a lack of analysis devices precluded further study site visits and sediment sampling at the time of the study. Therefore, we referred to the results of previous studies and analyzed relevant data in order to provide a rough indication of how mud particles are mobilized and how tidal current velocities influence the mobilization of the mud sediment in this case. Mobilization of the sediment was modeled through the use of the following formula [30]:

$$
u_{c r i t}^{\prime \prime}=6\left(\frac{D_{50}}{\delta}\right)^{-\frac{1}{3}} \sqrt{\left(\left(\frac{\rho_{S}}{\rho}-1\right) g D_{50}\right)}=0.36 \mathrm{~m} / \mathrm{s}
$$

where

$D_{50}$ (mean sediment diameter) $=0.0000300 \mathrm{~m}$ (retrieved from the previous study result in the Vietnamese Mekong Delta [31].

$\delta$ (boundary layer thickness) $=\delta=\frac{\sqrt{\vartheta T}}{\pi}=0.0005941 \mathrm{~m}$

$\rho_{\mathrm{s}}$ (specific gravity of sediment) $=2650 \mathrm{~kg} / \mathrm{m}^{3}$

$\rho$ (specific gravity of water) $=1000 \mathrm{~kg} / \mathrm{m}^{3}$.

$g$ (gravity acceleration $)=9.81 \mathrm{~m} / \mathrm{s}^{2}$

$\vartheta$ (kinematic water (fresh water without suspended matter) viscosity, with assumption of the temperature of $30^{\circ} \mathrm{C}=0.0000008 \mathrm{~m}^{2} / \mathrm{s}$

$\mathrm{T}($ wave period $)=4.35 \mathrm{~s}$ (retrieved from Figure 5) of the results.

An understanding of how wave action influences the mobilization of the sediment was achieved through the use of the linear shallow water wave theory.

$$
h_{\text {min }}=\frac{g H^{2}}{4\left(u_{c r i t}^{\prime \prime}\right)^{2}}=0.28 \mathrm{~m}
$$

where

$H$ (wave height) $=0.12 \mathrm{~m}$ (retrieved from Figure 6 of the results)

$g($ gravity acceleration $)=9.81 \mathrm{~m} / \mathrm{s}^{2}$

In addition, knowledge of settling velocity of mud sediment was achieved through reference to online sources [32]. This knowledge aimed to demonstrate how volatile the settling process was when the mud sediment was mobilized. 


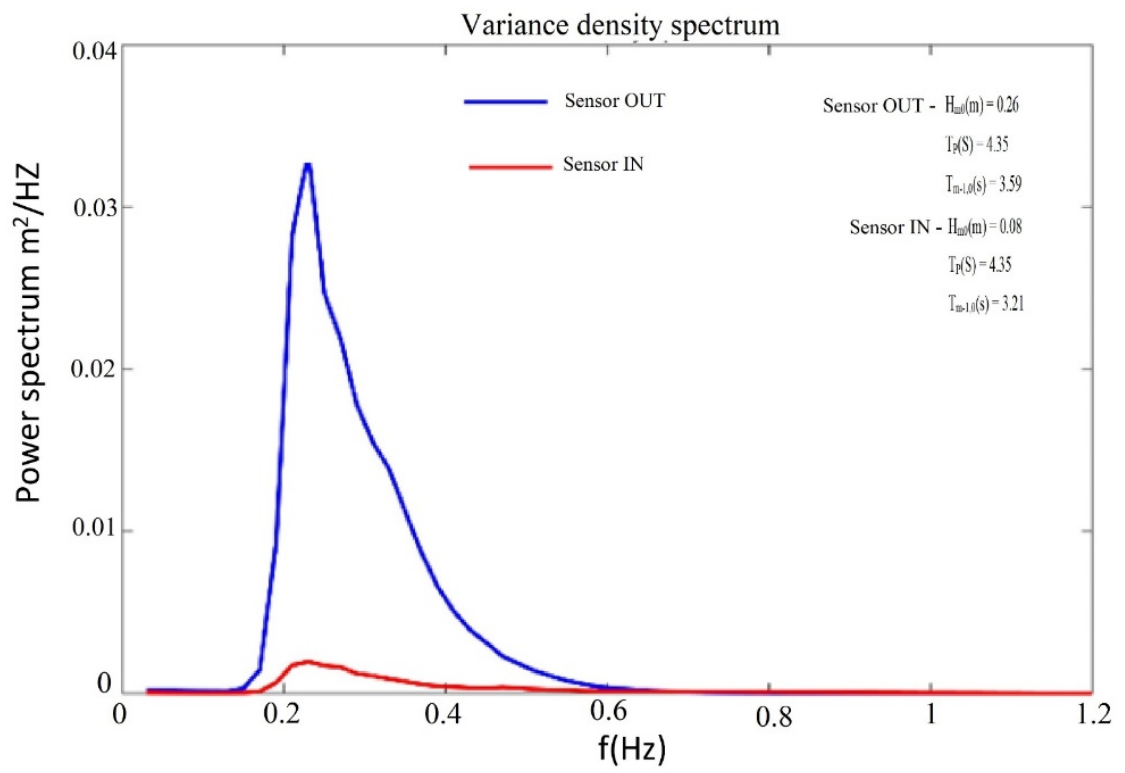

Figure 5. Wave spectrum with the blue line representing the power spectrum outside the HMS, and the red line indicating the power spectrum inside the sections.

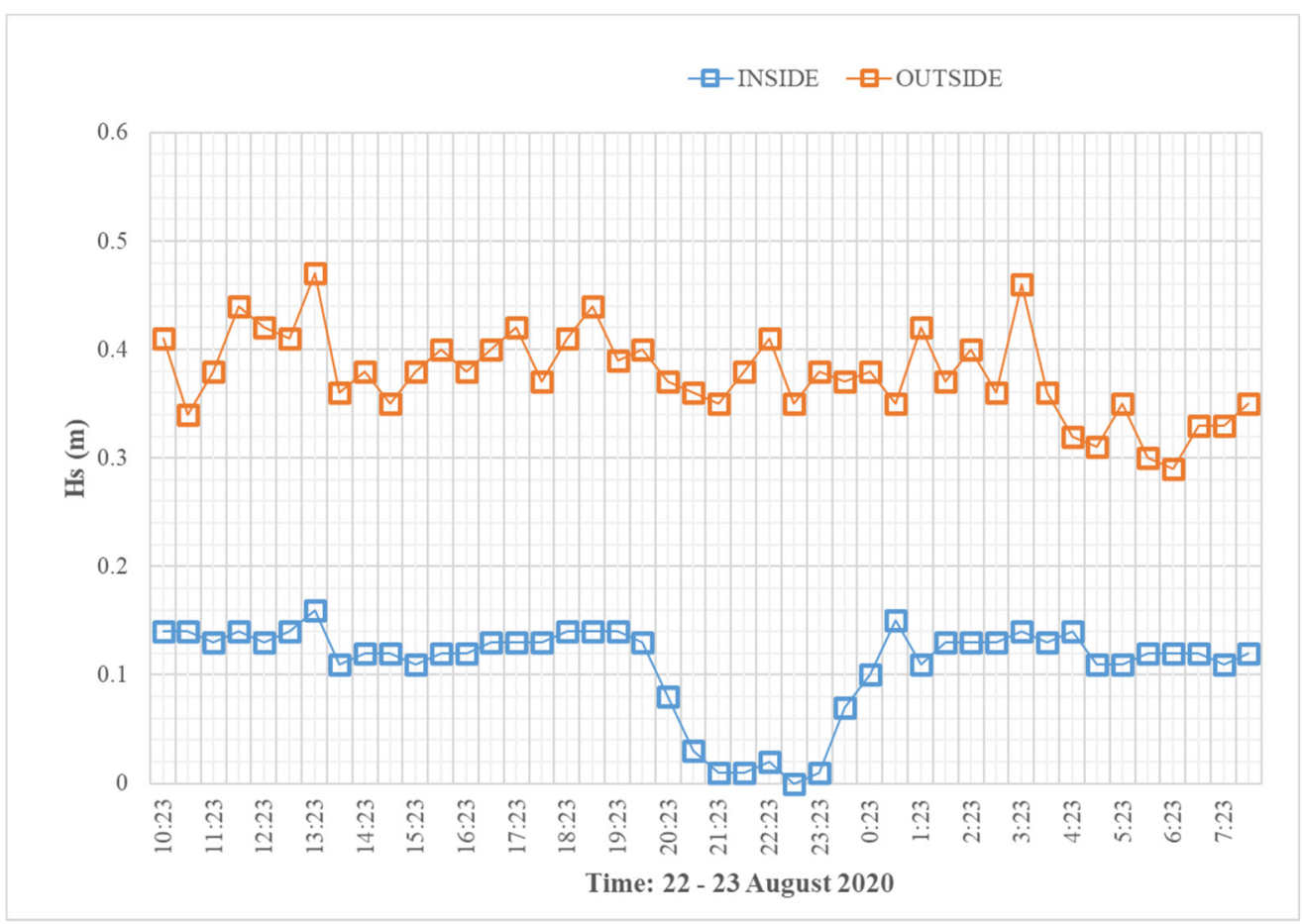

Figure 6. Wave height measurement.

\section{Results}

The study has provided results with respect to the sediment accumulation, wave spectrum and transmission, the stabilization process against the shoreline change in $\mathrm{Ca}$ Mau between 2013 and 2020, and natural regeneration of mangrove species. The following section presents the results in detail.

\subsection{Sediment Accumulation}

The recording showed that there was a low level of sediment accumulation across the sections (Figure 7). 


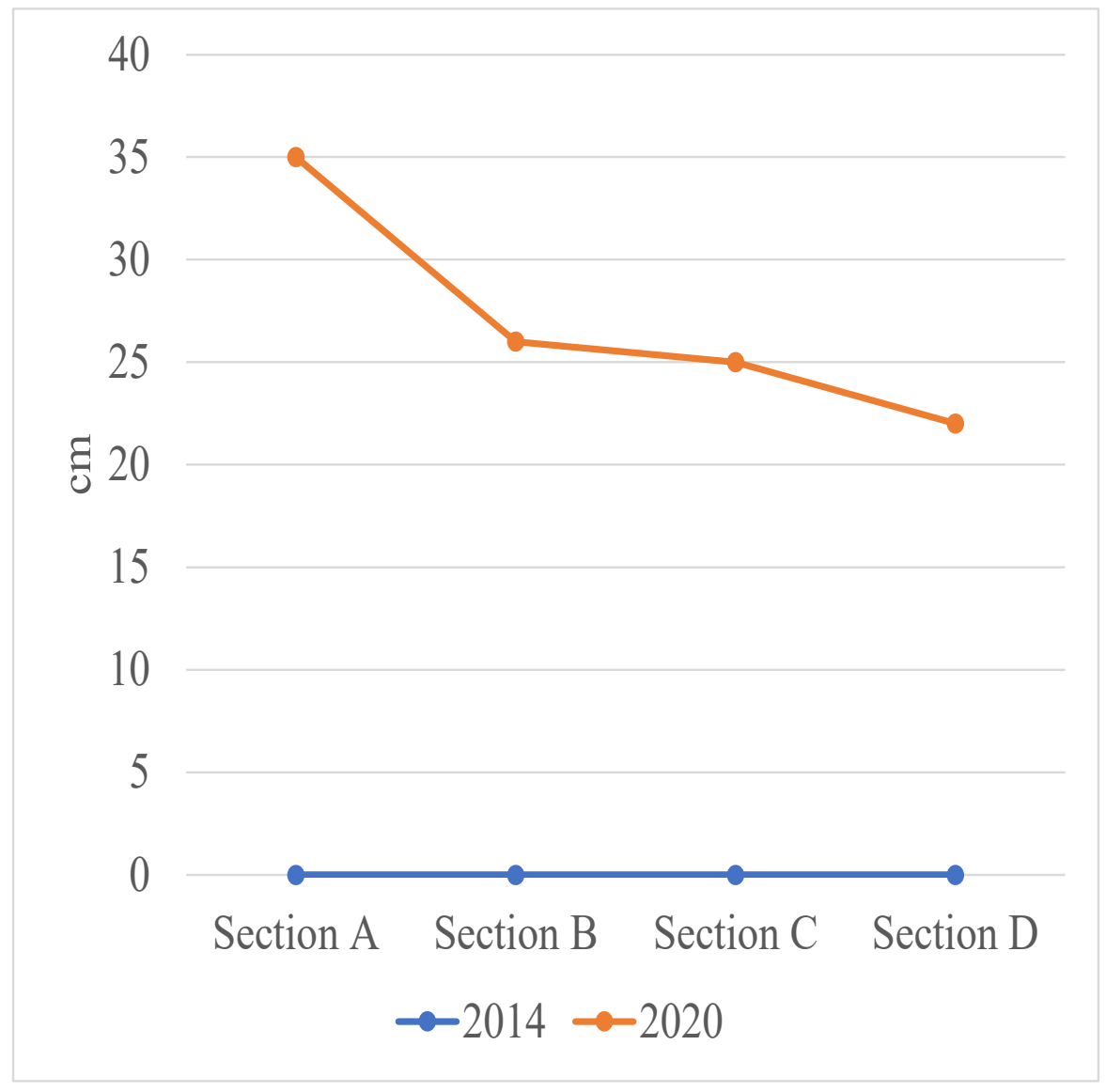

Figure 7. Accumulation of fine-grained sediment inside the sections between February 2014 and November 2020.

The field-based measurements indicated that the sections experienced a high level of TSS, possibly a few thousand mg/L on either side of the HMS in July 2017. This occurred when the southwest monsoon dominated. However, the sections gained a lower level of TSS than the foreshore of the HMS (Figure 8).

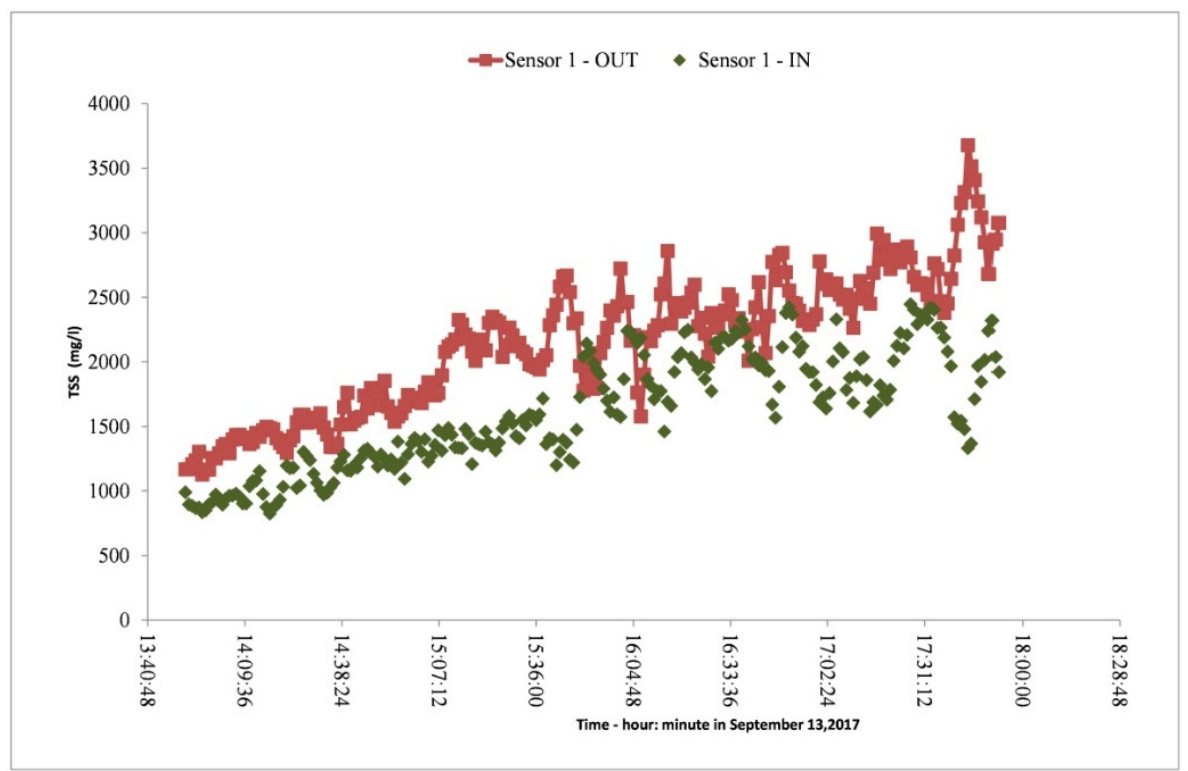

Figure 8. Cont. 


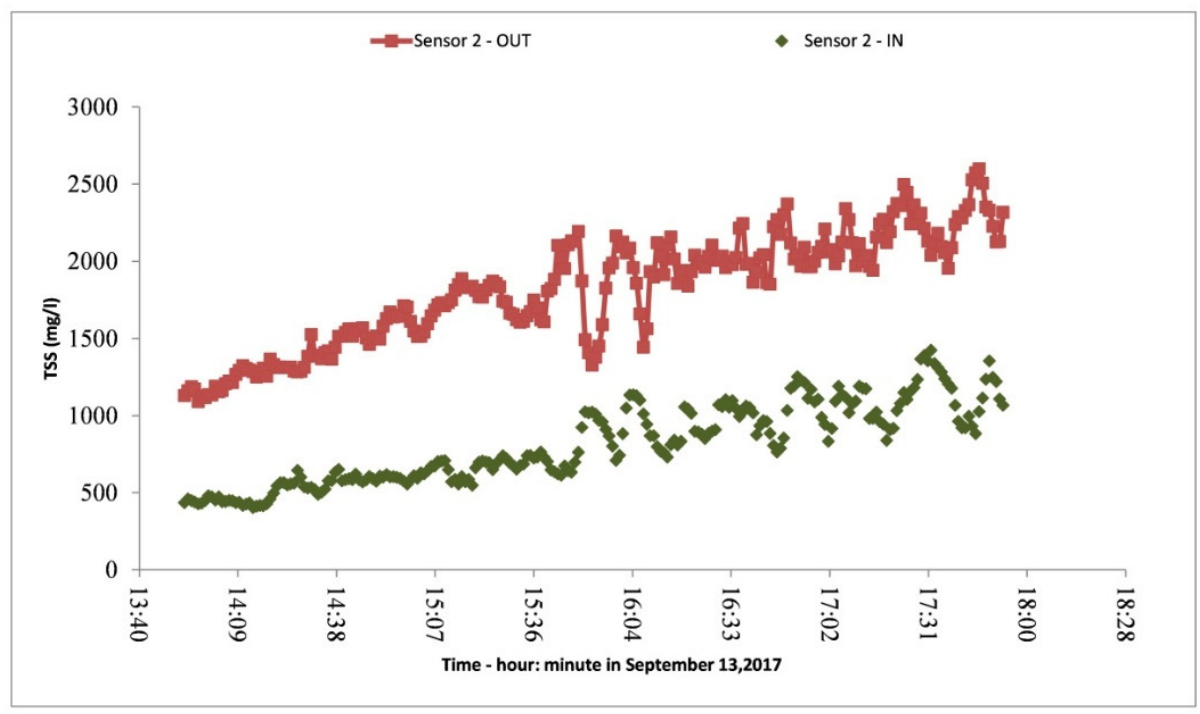

Figure 8. TSS recorded in the middle of the southwest monsoon on both sides of the HMS.

\subsection{Wave Spectrum and Transmission}

The HMS was effective in dissipating the energy of incident waves, even at high tides. The wave spectrum outside the HMS had a highly peaked wave power spectrum with a high energy distribution of more than $0.03 \mathrm{~Hz}$, while the spectrum inside the sections became flattened due to the energy attenuation provided by the HMS (Figure 5).

The wave height outside the HMS ranged between 0.29 and $0.47 \mathrm{~m}$, and between 0.01 and $0.16 \mathrm{~m}$ inside the HMS (Figure 6).

The transmission coefficient $K_{t}$ through the HMS ranged between 0.29 and 0.44 with respect to the $R_{c} / H_{i}$ value of more than 1.0 (Figure 9).

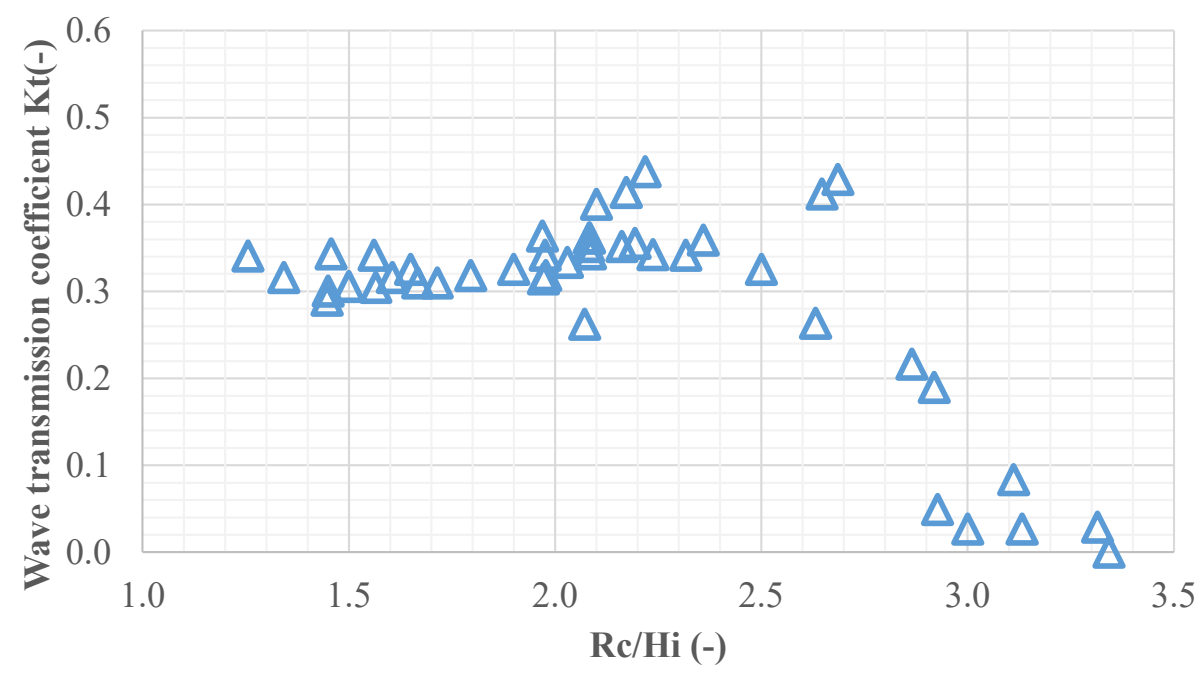

Figure 9. Wave transmission coefficients through the HMS.

From the field visits, it was apparent that the HMS was higher than incident wave crests, even at high tides, therefore preventing the waves from overtopping the structure. The HMS is structurally strong, with the maximum width of $2.6 \mathrm{~m}$ effectively attenuating the energy of incident waves, even at high tides. Fine-grained sediment accumulated in the foreshore of the structure, while liquid mud was observed around the openings along the HMS (Figure 10 and Table 2). 


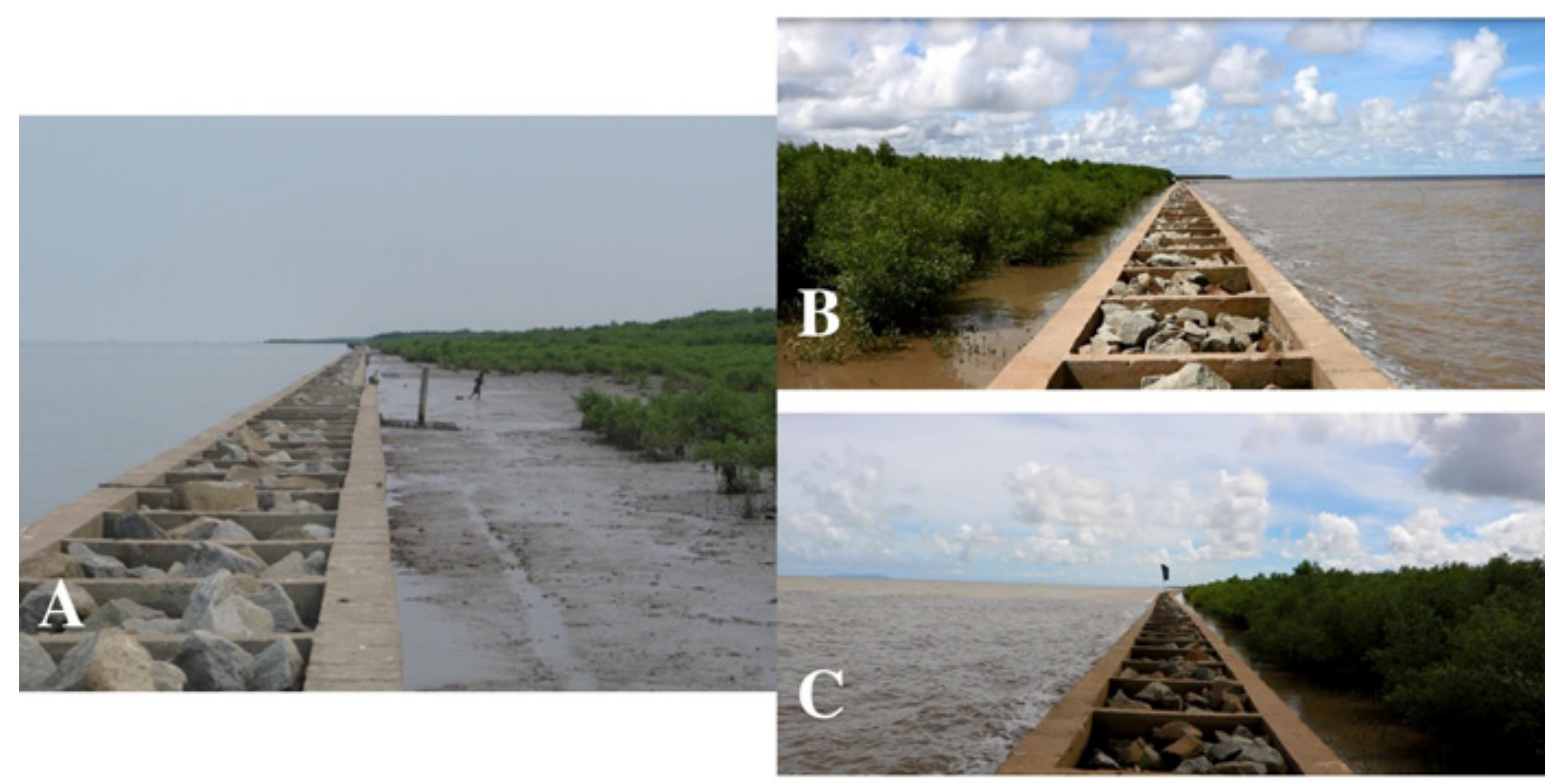

Figure 10. Incident waves at high tides did not overtop the HMS in November 2020, which was the period of highest tides in the area. (A) Low tide, and $(\mathbf{B}, \mathbf{C})$ high tides with strong incident waves.

Table 2. Record of the HMS status as at November 2020.

\begin{tabular}{|c|c|c|c|c|c|c|}
\hline \multirow[t]{2}{*}{ Section } & \multicolumn{2}{|c|}{ The Foreshore of the HMS } & \multicolumn{4}{|c|}{ Area Inside the Section } \\
\hline & $\begin{array}{c}\text { Fine-grained } \\
\text { mud } \\
\text { accumulated }\end{array}$ & Liquid mud & $\begin{array}{l}\text { Fine-grained } \\
\text { mud } \\
\text { accumulated }\end{array}$ & Liquid mud & $\begin{array}{l}\text { Survival of } \\
\text { transplanted } \\
\text { seedlings }\end{array}$ & $\begin{array}{l}\text { Natural regeneration } \\
\text { of mangrove species }\end{array}$ \\
\hline A & Yes & No & No & Yes & $100 \%$ & $10 \%$ \\
\hline B & Yes & No & No & Yes & $80 \%$ & $10 \%$ \\
\hline $\mathrm{C}$ & Yes & No & No & Yes & $80 \%$ & $10 \%$ \\
\hline $\mathrm{D}$ & Yes & No & No & Yes & $30 \%$ & $0 \%$ \\
\hline
\end{tabular}

The sections were still in liquid mud condition, with limited regeneration of mangrove trees in gaps among mother mangrove trees in Sections A, B and C and elevated soil surfaces (Figure 11 and Table 2).

The analysis derived from available literature suggested that with $h_{\min }=0.28 \mathrm{~m}$, the channel openings and the gaps were too shallow for the sediment to be stabilized under the influence of wave-induced action. It could be inferred from Figure 6 that the settling process was highly volatile when the mud was mobilized.

The semi-structured interviews with technical staff revealed that they were required to follow the Vietnamese regulations on controlling eroded coasts (the 2009 Program on Strengthening and Upgrading of the Sea Dyke Systems from Quang Ngai to Kien Giang provinces). The regulations stipulate that in eroded areas, in addition to the construction or upgrading of sea dykes as shoreline protection, intertidal mudflats, at least $500 \mathrm{~m}$ in width, should be established in order to create a mangrove belt along the Mekong coast and Ca Mau coast. However, the $500 \mathrm{~m}$ width was not possible in this area due to severe erosion and no mangrove regrowth was evident. The HMS was constructed as far on the seaward side as possible in order to create intertidal mudflats, as required by the 2009 Vietnamese regulations, which may explain the variation in distance between the HMS and the sea dyke among different sections. When the HMS was completed, the sediment accumulation and survival rates of transplanted seedlings were measured for reporting purposes, with additional measures taken only on request. Thus, no ongoing monitoring had been established. 


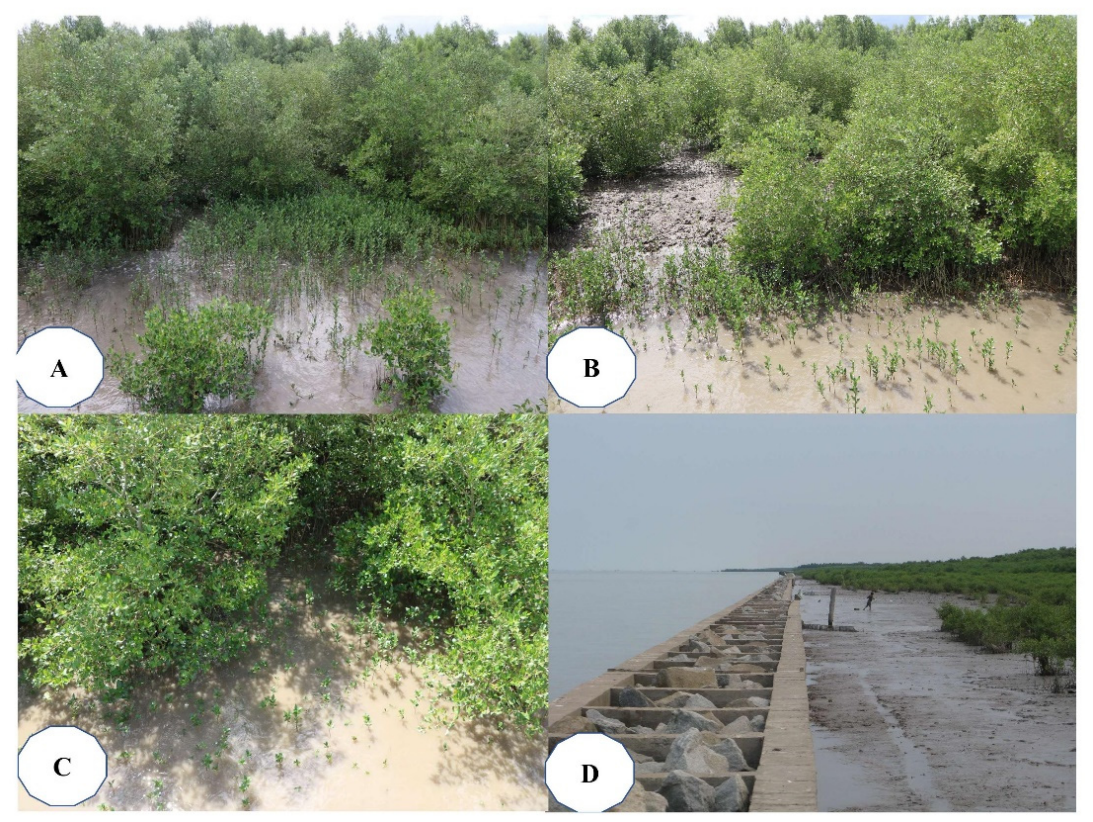

Figure 11. Natural regeneration among transplanted mangrove trees across the sections. (A) Section A; (B) section B; (C) section C; (D) section D.

\subsection{The Stabilization Process}

The image analysis revealed that the sections experienced variable levels of stabilization between 2013 and 2020. Of the four sections, Section A was entirely stabilized with the largest coverage of mangrove species, with Section D the least stabilized and with lowest mangrove coverage (Figure 12).
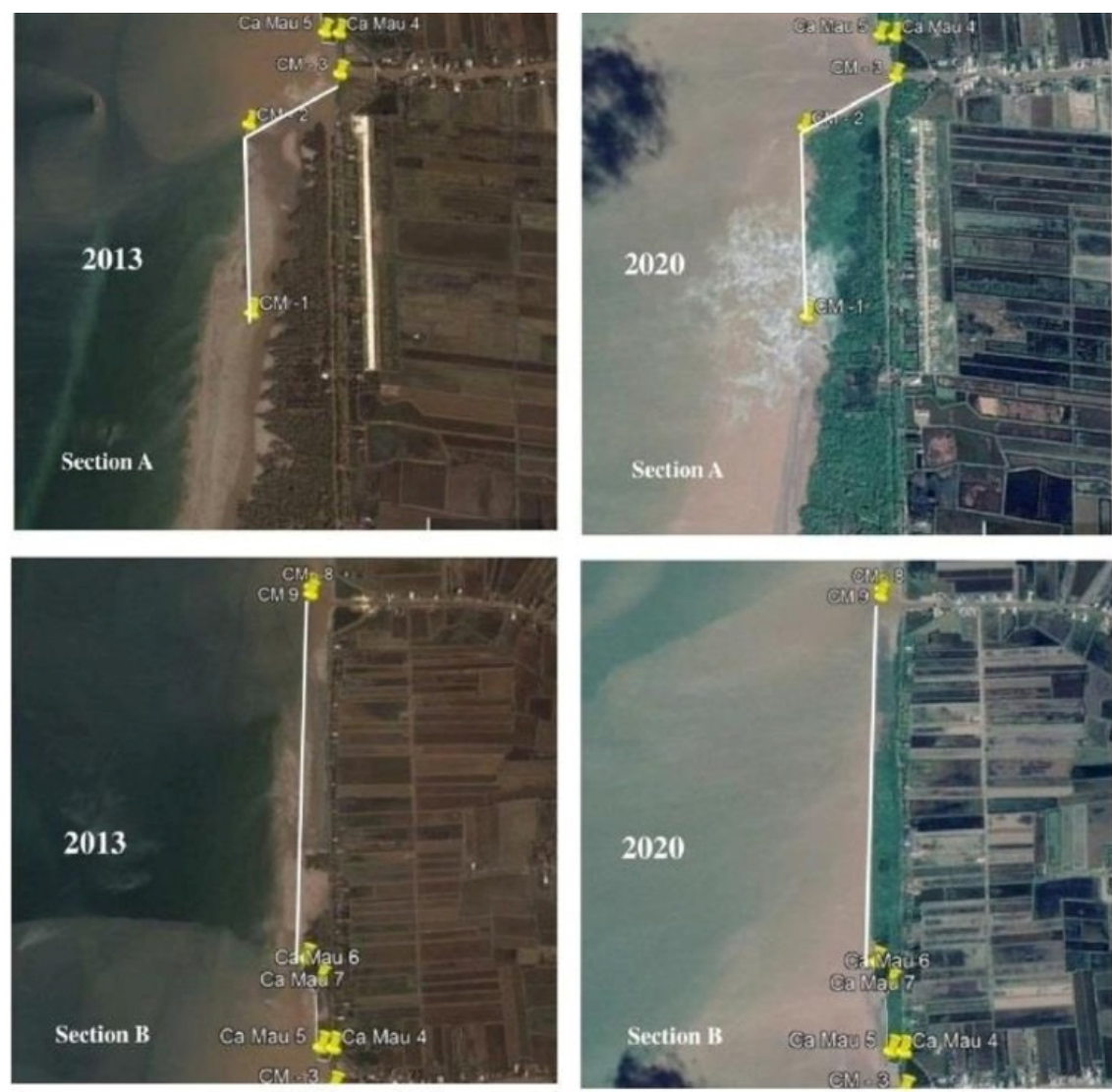

Figure 12. Cont. 

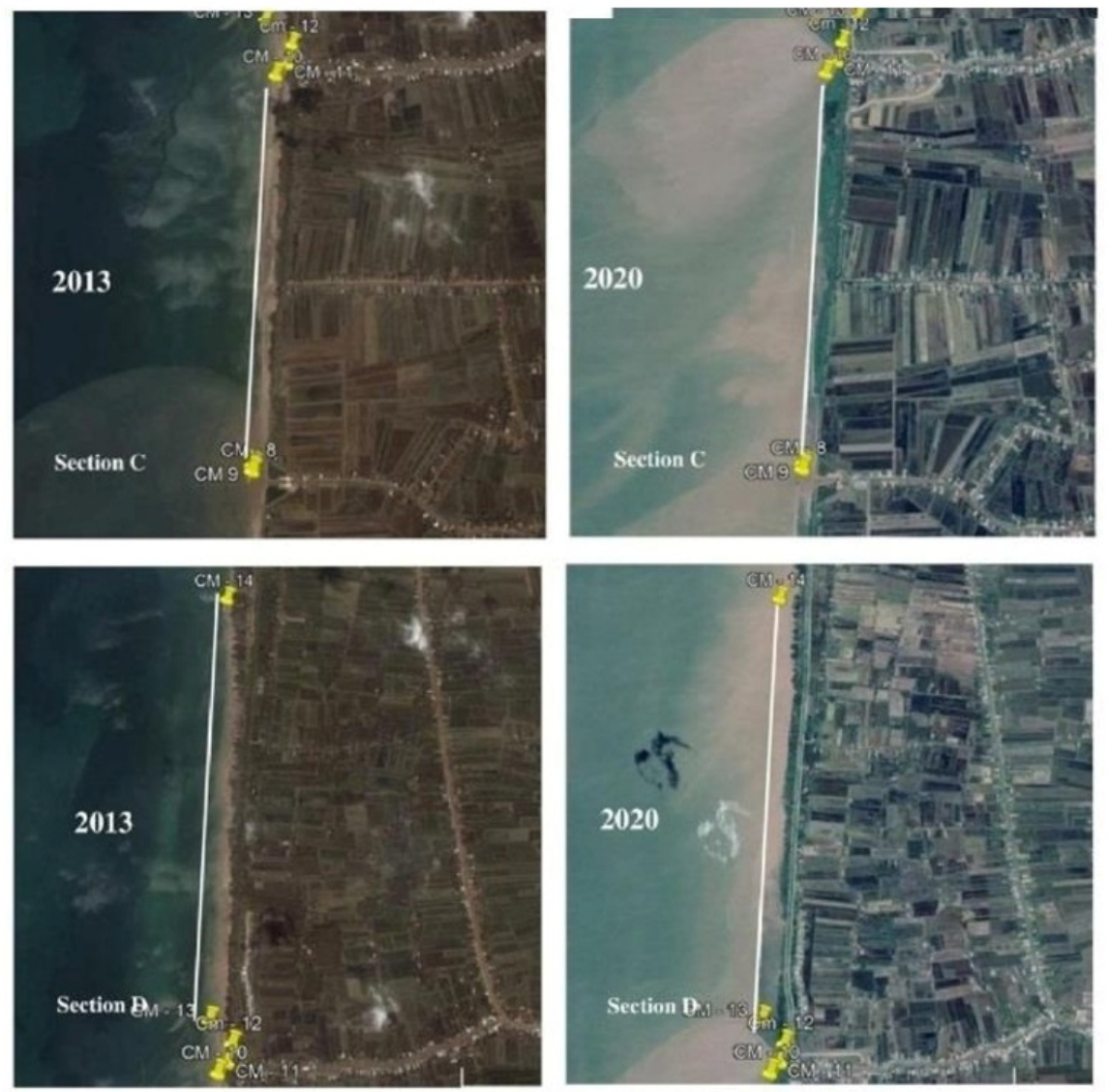

Figure 12. Changes across the sections between 2013 and 2020. The white line represents the HMS.

\section{Discussion}

The study addressed the sediment accumulation, wave attenuation and stabilization processes. These issues are discussed in detail in the following sections.

\subsection{HMS and the Stabilization of the Eroded Muddy Coast}

Eroded sites are not stabilized until fine-grained sediment accumulates and mangrove species regenerate [33,34]. As of December 2020, the Huong Mai area had failed to reach that threshold, with limited accumulation of sediment and natural mangrove regeneration in the sections. The limited sediment accumulation was possibly due to the fact that the HMS itself prevented the sediment from being transported into the sections, as shown in Figures 7-9 and Table 2. The accumulated sediment along the sections may possibly be the sediment trapped by the construction of the HMS. Liquid sediment was found in deeper areas inside the sections which had not been reclaimed. The field-based observations were supported by the field-based measurements and analysis results, as presented in Section 3.2 and Figures $6-8$ of this study.

By contrast, sediment gradually accumulated on the foreshore of the HMS as shown in Table 2. The limited sediment accumulation and liquid sediment among the gaps and the channel openings did not create favorable conditions for mangrove species to regenerate, as shown in Figure 11 and Table 2. The amount of accumulation and natural regeneration in the sections were somewhat low in comparison with those of the Vam Ray model [35], which was also located on the western side of the Mekong Delta coast.

The HMS was effective in reducing up to around $70 \%$ of incident wave energy (Figures 8 and 9). Thus, transplanted seedlings were well-protected in the sections, as shown in Figures 10 and 11. In addition to the protection from the HMS, transplanted seedlings' survival was aided by the use of landfill to elevate soil, thus providing a more favorable growing condition. This may explain why Sections A, B and C experienced 
higher survival rates than Section D, which still contained deep liquid mud, which is unsuitable for either transplanted seedlings or natural mangrove regeneration. The high survival rates of transplanted seedlings on the elevated soil surface strongly concur with previous conclusions that topographical elements must be secured before restoration is made [36-38]. In addition, the HMS was more effective in protecting transplanted seedlings than offshore breakwaters implemented in Malaysia [8,9] and Thailand [10].

However, transplantation at high densities (10,000 seedlings/ha) is a matter of concern. Previous studies show transplantation to be both costly and unnecessary, because mangrove species will not naturally regenerate until intended restoration sites are stabilized $[33,35]$. In addition, transplantation using a single mangrove species is likely to result in ecological and physical changes to muddy coasts $[39,40]$. Of further concern, single-aged mature mangrove trees in high-density stands are highly likely to deteriorate without adequate sediment and nutrient supplies [40]. So far, the transplanted seedlings have grown in the absence of large amounts of accumulated fine-grained sediment, but these transplanted seedlings must be closely monitored in the longer term.

In other words, the HMS has had only a limited effect on the stabilization of the eroded muddy coast, given the capital investment involved. It took almost 10 years for the Huong Mai coast to reach this level while the Vam Ray model, Kien Giang, also located on the western side of the Mekong Delta of Vietnam, took only seven years to be completely stabilized with a high level of soil compaction and robust regeneration of local mangrove species [35].

\subsection{HMS and Communicating the Results of HMS}

Monitoring and evaluation are crucial in drawing lessons from a project and making further recommendations, particularly in development projects [41]. Poor information sharing and inadequate reporting are very likely to result in failure when attempting to replicate successful models elsewhere [35]. It is common for government agencies, when reviewing restoration projects, to focus on delivery rather than outcomes [42]. This is highly likely to be the case with the HMS. The longevity of the HMS appears to be the only "evidence" of its efficacy in stabilizing the eroded muddy coast. As no ongoing monitoring system has been established, it is difficult to know survival rates of transplanted seedlings, or the accumulation of fine-grained sediment. Likewise, the gaps were not adequately explained, which makes effective replication of this design elsewhere in the region problematic. Inappropriate replication has occurred in Khanh Binh Tay and Tran Van Thoi [24].

A remaining issue involves the compaction of liquid mud in the remaining gap of Section D and the deep areas surrounding the channel openings of the HMS. Avicennia species as pioneers assist in trapping and compacting sediment within muddy environments [35,43]. However, the transplantation of this species in the sections did not resolve this issue because the current topographical conditions were unsuitable for the growth of this species or other species (see Figures 11D and 12). Therefore, further measures will need to be taken. One measure involves the complete elevation of the gaps to provide suitable mangrove substrates [36-38]. A second measure involves the construction of supplementary structures inside the gaps to compartmentalize the gaps. The compartmentalization would provide additional wave dissipation, thus further aid siltation. Supplementary structures could include melaleuca fences of the Vam Ray model $[34,35]$. A further measure involves a redesign of the HMS, with the aim of accumulating additional sediment transported onshore by incident waves, particularly at high tides that would help to build up these areas. This measure would use the sediment accumulated in front of the HMS. The crest of the HMS could be lowered, the width narrowed, and gaps adequately explained, or more opening areas created to connect the sedimentation process between the sections and the sea. The lowering would allow waves to overtop the structure, thus allowing fine-grained sediment to accumulate within the restoration sections. The narrowing should be ideally undertaken by reducing gaps between the two rows of concrete piles and using 
less granite rock. The increase in porosity would allow sediment to be transported through the HMS. The construction of additional structures and the redesign of existing structures, while incurring additional costs, are likely to be more cost-effective than the elevation of all the gaps behind the HMS.

With respect to the liquid mud in areas around the openings, granulometric information and knowledge of seabed configuration must be obtained in order to thoroughly understand how muddy sediments are mobilized and how tidal current velocities affect the muddy sedimentation in the openings. This knowledge would help better locate the structures and adjust structural designs. Ideally, these latter measures would not be implemented until biological and hydraulic parameters were fully analyzed. The choice of appropriate measures, however, entirely depends on the local political will. In addition, if transplantation is decided upon, multiple mangrove species should be selected in order to avoid the possible consequence of transplantation of a single species, as previously outlined [35].

\section{Conclusions and Recommendations}

Fine-grained sediment accumulation in combination with wave attenuation are effective indicators for understanding the efficacy of the HMS in stabilizing the Huong Mai eroded muddy coast. The HMS has been of limited efficacy in stabilizing the eroded muddy coast in Huong Mai, Tieu Dua, Ca Mau. While it effectively dissipates incident wave energy, sediment has not accumulated rearward to the degree expected due to inappropriate structural design. The lack of ongoing monitoring system makes a thorough evaluation of its efficacy difficult, while inadequate explanation of the structural design makes its replications in other locations problematic.

Granulometric tests should be undertaken before similar structures are designed in order to gain a thorough knowledge of seabed configuration and possibility of mobilization of mud sediment. This knowledge would substantially assist in explaining positions of the structures and improving the efficacy in stabilizing eroded muddy coasts. A monitoring program should be established in order to assess the impacts of these structures on muddy coast stabilization and to draw lessons in order to more effectively protect these types of coastlines in the future.

Author Contributions: This review paper was written with contributions provided by all authors. T.T.L. was responsible for searching data/publications, conceptual format, and preparing the manuscript. L.X.T. was responsible for collecting field-based measurements. N.T.A., N.T.T., T.A.D. were involved in data analysis and preparing the manuscript. N.T.P. was in charge of analyzing the data, and finalizing, proofreading and submitting the manuscript. All authors have read and agreed to the published version of the manuscript.

Funding: This research received no external funding.

Institutional Review Board Statement: Not applicable.

Informed Consent Statement: Not applicable.

Data Availability Statement: Data available in a publicly accessible repository.

Acknowledgments: The authors would like to thank the Australia Awards-Endeavour Research Fellowship and the Aus4Skills Vietnam for grants. The authors would also like to thank James Moloney for editorial service, and the anonymous reviewers for their helpful comments.

Conflicts of Interest: The authors declare no conflict of interest.

\section{References}

1. Nordstrom, K.F. Beaches and Dunes of Developed Coasts; Cambridge University Press (CUP): Cambridge, UK, 2000.

2. Dugan, J.E.; Airoldi, L.; Chapman, M.G.; Walker, S.J.; Schlacher, T. Estuarine and coastal structures: Environmental effects, a focus on shore and nearshore structures. In Treatise on Estuarine and Coastal Science, 1st ed.; McLusky, D., Wolanski, E., Eds.; Elsevier Inc.: London, UK, 2011; Volume 8, pp. 1-3. 
3. Koffler, A.; Choura, M.; Bendriss, A.; Zengerink, E. Geosynthetics in protection against erosion for river and coastal banks and marine and hydraulic construction. J. Coast. Conserv. 2008, 12, 11-17. [CrossRef]

4. Rangel-Buitrago, N.; Williams, A.; Anfuso, G. Hard protection structures as a principal coastal erosion management strategy along the Caribbean coast of Colombia. A chronicle of pitfalls. Ocean Coast. Manag. 2018, 156, 58-75. [CrossRef]

5. Elkafrawy, S.B.; Basheer, M.A.; Mohamed, H.M.; Naguib, D.M. Applications of remote sensing and GIS techniques to evaluate the effectiveness of coastal structures along Burullus headland-Eastern Nile Delta, Egypt. Egypt. J. Remote Sens. Space Sci. 2020. [CrossRef]

6. Lima, M.; Coelho, C.; Veloso-Gomes, F.; Roebeling, P. An integrated physical and cost-benefit approach to assess groins as a coastal erosion mitigation strategy. Coast. Eng. 2020, 156, 103614. [CrossRef]

7. Boda, C.S. From economic choice to social choice in coastal management: A critical assessment of the use of cost-benefit analysis in the evaluation of an erosion control project in Flagler County, Florida, U.S.A. Ocean Coast. Manag. 2018, 162, 85-99. [CrossRef]

8. Stanley, O.D.; Lewis, R.R., III. Strategies for mangrove rehabilitation in an eroded coastline of Selangor, peninsular Malaysia. J. Coast. Dev. 2009, 12, 142-154.

9. Hashim, R.; Kamali, B.; Tamin, N.M.; Zakaria, R. An integrated approach to coastal rehabilitation: Mangrove restoration in Sungai Haji Dorani, Malaysia. Estuar. Coast. Shelf Sci. 2010, 86, 118-124. [CrossRef]

10. Saengsupavanich, C. Erosion protection options of a muddy coastline in Thailand: Stakeholders' shared responsibilities. Ocean Coast. Manag. 2013, 83, 81-90. [CrossRef]

11. Tung, N.T. Basic Scientific Research for Selecting Engineered Solutions to Protect the Western Muddy Coast and to Rehabilitate Mangroves in Khanh Tien Commune, Uminh District, Ca Mau Province. Master's Thesis, University of Water Resources of Ho Chi Minh City, Ho Chi Minh City, Vietnam, 2013.

12. Le Xuan, T.; Ba, H.T.; Le Manh, H.; Van, D.D.; Nguyen, N.M.; Wright, D.P.; Bui, V.H.; Mai, S.T.; Anh, D.T. Hydraulic performance and wave transmission through pile-rock breakwaters. Ocean Eng. 2020, 218, 108229. [CrossRef]

13. Woodroffe, C.D. Coasts: Form, Process, Evolution; Cambridge University Press: Cambridge, UK, 2002.

14. Wang, Y.; Healy, T.; Augustinus, P.; Baba, M.; Bao, C.; Flemming, B.; Fortes, M.; Han, M.; Marone, E.; Mehta, A.; et al. Chapter Two Definition, properties, and classification of muddy coasts. Ecol. Poole Harb. 2002, 4, 9-18. [CrossRef]

15. Tien, H.; Anh, N.T.; Phong, N.T.; Nhat, M.M. Ecological Engineering and Restoration of Eroded Muddy Coasts in South East Asia: Knowledge Gaps and Recommendations. Sustainability 2021, 13, 1248. [CrossRef]

16. Anthony, E.J.; Brunier, G.; Besset, M.; Goichot, M.; Dussouillez, P.; Nguyen, V.L. Linking rapid erosion of the Mekong River delta to human activities. Sci. Rep. 2015, 5, 14745. [CrossRef]

17. Phan, L.K.; Vries, J.S.V.T.D.; Stive, M.J. Coastal Mangrove Squeeze in the Mekong Delta. J. Coast. Res. 2015, 300, 233-243. [CrossRef]

18. Besset, M.; Gratiot, N.; Anthony, E.J.; Bouchette, F.; Goichot, M.; Marchesiello, P. Mangroves and shoreline erosion in the Mekong River delta, Viet Nam. Estuar. Coast. Shelf Sci. 2019, 226, 106263. [CrossRef]

19. VPM. Program to Upgrading and Reinforcing the Sea Dyke System from Quang Ngai to Kien Giang Provinces; VPM: Hanoi, Vietnam, 2009.

20. VPM. The Strategy for Managing Integrated Coastal Zones of Vietnam; VPM: Hanoi, Vietnam, 2014.

21. VPM. Regulations of Managing Protected Forests; VPM: Hanoi, Vietnam, 2015.

22. MARD. Coastal Mangrove Forests in the Mekong Delta Decreased in Area over the Past 15 Years. Available online: http://vea.gov.vn/vn/quanlymt/baotondadangsh/tintuchoatdong/tintucvasukien/tintuc/Pages/Di\%E1\%BB\%87n-t\%C3 \%ADch-r $\%$ E1\%BB $\%$ ABng-ng $\%$ E1\%BA $\% A D p-m \% E 1 \% B A \% B 7 n-\% C 4 \% 90 \% E 1 \% B B \% 93 n g-b \% E 1 \% B A \% B 1 n g-s \% C 3 \% B 4 n g-C \%$ E1\%BB\%ADu-Long-gi\%E1\%BA\%A3m-trong-5-n\%C4\%83m-qua.aspx (accessed on 12 December 2018).

23. Phong, N.T.; Parnell, K.E.; Cottrell, A. Human activities and coastal erosion on the Kien Giang coast, Vietnam. J. Coast. Conserv. 2017, 21, 967-979. [CrossRef]

24. Ca Mau PPC. Reporting Saline Intrusion and Measures for Adaptation to Coastal Erosion in Ca Mau; Ca Mau PPC: Ca Mau, Vietnam, 2019.

25. VPM. Direction to Ministry of Finance, Ministry of Foreign Affairs, Ca Mau PPC and Kien Giang PPC with Respect to the Loan Agreement with the Government of Germany; VPM: Hanoi, Vietnam, 2012.

26. Ca Mau PPC. Reporting the Feasibility Study of the Proposed Project' Integrated Coastal Protection and Mangrove Belt Rehabilitation Project in Ca Mau Province'; Ca Mau PPC: Ca Mau, Vietnam, 2012.

27. Kien Giang PPC. Reporting the Feasibility Study of the Proposed Project' Integrated Coastal Protection and Mangrove Belt Rehabilitation Project in Kien Giang'; Ca Mau PPC: Ca Mau, Vietnam, 2013.

28. Thanh Nien. Waves Overtopping a 3 m Crested Sea Dyke in the Western side of Ca Mau Province 'Never Happened'. Available online: https:/ / thanhnien.vn/thoi-su/song-danh-vuot-mat-de-bien-tay-co-cao-trinh-hon-3-met-chua-tung-xay-ra-1110867. html (accessed on 9 March 2021).

29. Thanh, L.V. Project: Studying and Testing the Technology of Breakwater for Creating the Sedimentation Yards to Prevent West Sea Dyke Landslide; Vietnam Institute of Coastal and Offshore Engineering: Ho Chi Minh City, Vietnam, 2013.

30. Sawamoto, M.; Yamashita, T. Sediment Transport in Sheet Flow Regimes. In Proceedings of the Coastal Sediments 87 Conferences, New Orleans, LA, USA, 12-13 May 1987; pp. 415-423. 
31. Thanh, N.T.; Stattegger, K.; Unverricht, D.; Nittrouer, C.; Van Phach, P.; Liu, P.; DeMaster, D.; Dung, B.V.; Anh, L.D.; Dong, M.D. Surface sediment grain-size distribution and sediment transport in the subaqueous Mekong Delta, Vietnam. Vietnam J. EARTH Sci. 2017, 39, 193-209. [CrossRef]

32. Leovanrijin. Settling Velocity of Mud. Available online: https://leovanrijn-sediment.com/papers/Settlingvelocity2020.pdf (accessed on 12 April 2021).

33. Kamali, B.; Hashim, R. Mangrove restoration without planting. Ecol. Eng. 2011, 37, 387-391. [CrossRef]

34. Nguyen, T.; Parnell, K.E. Gradual expansion of mangrove areas as an ecological solution for stabilizing a severely eroded mangrove dominated muddy coast. Ecol. Eng. 2017, 107, 239-243. [CrossRef]

35. Nguyen, T.; Van Tam, N.; Quoi, L.P.; Parnell, K.E. Community perspectives on an internationally funded mangrove restoration project: Kien Giang province, Vietnam. Ocean Coast. Manag. 2016, 119, 146-154. [CrossRef]

36. Lewis, R.R., III. Ecological engineering for successful management and restoration of mangrove forests. Ecol. Eng. 2005, 24, 403-418. [CrossRef]

37. Winterwerp, J.C.; Borst, W.G.; De Vries, M.B. Pilot Study on the Erosion and Rehabilitation of a Mangrove Mud Coast. J. Coast. Res. 2005, 212, 223-230. [CrossRef]

38. Winterwerp, J.C.; Erftemeijer, P.L.A.; Suryadiputra, N.; van Eijk, P.; Zhang, L. Defining Eco-Morphodynamic Requirements for Rehabilitating Eroding Mangrove-Mud Coasts. Wetlands 2013, 33, 515-526. [CrossRef]

39. Nguyen, T.P.; Luom, T.T.; Parnell, K.E. Mangrove transplantation in Brebes Regency, Indonesia: Lessons and recommendations. Ocean Coast. Manag. 2017, 149, 12-21. [CrossRef]

40. Nguyen, T.P.; Parnell, K.E. Coastal land use planning in Ben Tre, Vietnam: Constraints and recommendations. Heliyon 2019, 5, e01487. [CrossRef] [PubMed]

41. IFAD. Managing for Impact in Rural Development: A Guide for Project M\&E. 2002. Available online: https://www.ifad.org/ documents/38714182/39723123/toc.pdf/e7c718e2-56b9-4f60-b404-3f31448a38a2 (accessed on 13 March 2021).

42. Anderson, M.B.; Brown, B.; Jean, I. Time to Listen: Hearing People on the Receiving End of International Aid; CDA Collaborative Learning Projects: Cambridge, MA, USA, 2012.

43. Duke, N. Australia's Mangroves: The Authoritative Guide to Australia's Mangrove Plants; University of Queensland: Brisbane, Australia, 2006. 